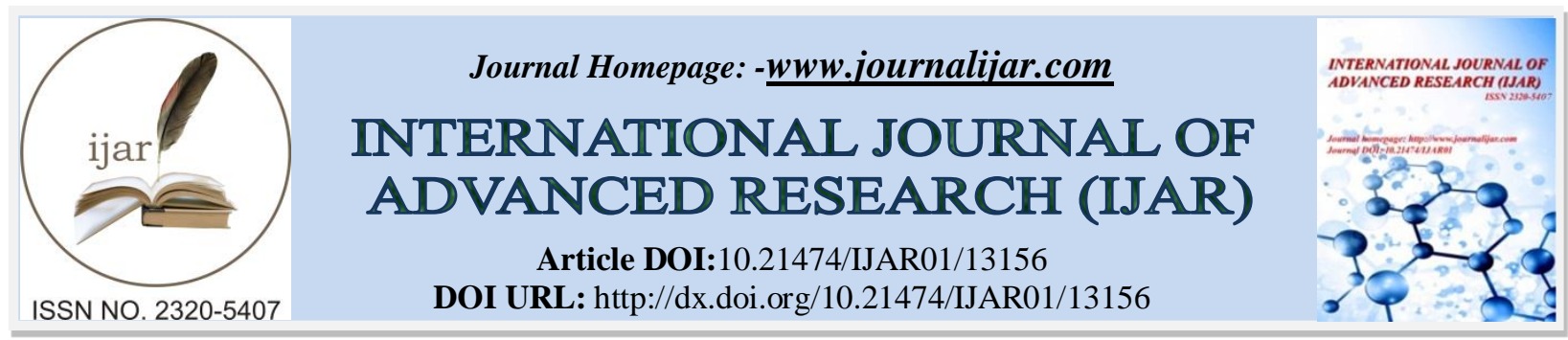

RESEARCH ARTICLE

\title{
THE INFLUENCE OF MADRASA SUPERVISON PRINCIPLE AND ORGANIZATIONAL CLIMATE ON TEACHER WORK MOTIVATION AND IT'S IMPLICATIONS ON TEACHER PERFORMANCE
}

Siti Afifatun, Yetri Hasan and Agus Jatmiko

Post-Graduate Program of Islamic Education Management Study Program, Raden Intan State Islamic University of Lampung, Indonesia.

\section{Manuscript Info}

.........................

Manuscript History

Received: 15 May 2021

Final Accepted: 18 June 2021

Published: July 2021

Key words:-

Academic Supervision, Organizational Climate, Work Motivation, Teacher

Performance

\section{Abstract}

The purpose of this study was to obtain empirical evidence about; The contribution of the supervision the madrasah principal to the performance of Madrasah Aliyah (MA) teachers throughout; The contribution of organizational climate to the performance of Madrasah Aliyah teachers; The contribution of MA teachers' work motivation to the performance of Madrasah Aliyah teachers; The contribution of the madrasa principal's academic supervision, organizational climate, and work motivation to the performance of MA teachersin North Lampung district. This research was carried out using aquantitative approach and associative descriptive method.The population is public and private MA teachersin North Lampung district, totaling 177 people who are the research sample using quota sampling technique. Research data were collected through question naires and analyzed using descriptive statistical techniques and pathanalysis. The results of this study are; academic supervision of the Madrasah Principal, organizational climate, and teachers' work motivation to gether proved to have appositive and significant effect on the performance of MA teachers with a contribution of $62.4 \%$. Partially, teacher work motivation most dominantly affects teacher performance.

Copy Right, IJAR, 2021,. All rights reserved.

\section{Introduction:-}

Along with the development of the recent now, in the global era with its characteristics: critical thinking, communicative, collaborative and creative. So madrasa teachers have a very important role in implementing these four characteristics, when they are not applied, students will not succeed in achieving their goals and the goals of National Education will not be achieved. Madrasah Aliyah a religious education institution has a very important role, but to achieve it also faces challenge.

The challenge for Islamic educational institutions is to produce humans who have a balance in their views of life, not only having religious knowledge but also having general knowledge and skills or competencies that are useful for life today. In addition, the influence of the globalization era has also caused the moral decline of the younger generation, such as: fights between students, drug abuse, free sex behavior, and so on, causing parents to begin to realize the importance of religious education for their children.

Corresponding Author:- Siti Afifatun

Address:- Post-Graduate Program of Islamic Education Management Study Program, Raden Intan State Islamic University of Lampung, Indonesia. 
Facing these challenges and the very high public response to the importance of education, especially religious education for their children. In response to the wishes and needs of the community, in all corners of the North Lampung region, many Islamic educational institutions or Madrasah Aliyah have been established in remote areas. area. Of course, the establishment of Madrasah Aliyah in remote areas must be monitored and paid attention to by the Ministry of Religion of the Republic of Indonesia in North Lampung Regency, both operational standards in the implementation of Teaching and Learning Activities and the performance of the teachers in order to produce quality graduates.

Teacher performance is important in determining the success of students and schools. According to some expert opinions, there are many factors that are thought to affect teacher performance in learning, including; leadership of the principal both managerially and academically, curriculum, educational qualifications, teacher work motivation, organizational climate, work culture, rewards/salaries, training and education attended, and others.

Effective learning is characterized by creative and independent students. This is created because the teacher's performance is high. However, to produce high-performing and professional teachers is also not an easy task..

Several things that affect less than optimal performance include; 1) a person's internal factors in the form of intellectual weakness, psychological weakness, physical weakness, teacher work motivation, personality factors, finances, job preparation, teacher professionalism and value orientation. 2) Organizational problems in the form of systems, group roles, leadership of the madrasa head both managerial and academic, academic supervision, supervisory behavior, organizational climate; 3) Problems from outside the individual in the form of family, work atmosphere, organizational culture, economic conditions, political conditions, legal conditions, social order, the job market, technological developments and unions.

Based on the pre-survey at Madrasah Aliyah in North Lampung, the performance of MA teachers in North Lampung is still not optimal, it needs to be improved again. some teachers in MA are still not in accordance with the field they are in, there are also those who have not S1 but because no one teaches. Also there are still those who have not made lesson plans. Then have not filled in the Teacher Performance Assessment programmatically.

The cause of the teacher's performance is not optimal, among others, allegedly due to the absence of guidance by the principal, namely academic supervision. This is in accordance with Mantja's opinion, the head of a madrasa in a madrasa has several managerial functions, namely as a manager, supervisor, and administrator (educational leader) in a madrasa to improve teacher performance. Academic supervision is an act of helping, fostering and providing opportunities for teachers to develop their competencies in order to increase the teacher's performance. Supported by Ahmad Maulid's opinion in previous research, it was stated that the supervision of the madrasah principal had a positive and significant influence on the performance of MA teachers. The results of the study stated that the higher the implementation of the madrasa principal's academic supervision, the higher the teacher's performance.

Another factor that is thought to influence teacher performance is the organizational climate. Organizational climate is a situation and condition outside of humans in the form of comfortable facilities and infrastructure (ventilation, comfortable room), and leadership behavior towards subordinates, colleagues in working together, respecting each other, getting rewards when successful and the participation of all school members. in achieving organizational goals. When the school atmosphere is a conducive organizational climate, then all school members will be better able to improve their performance. This is in line with Dedeh's opinion in his research, which concludes that teacher performance is significantly influenced by organizational climate with an influence of $67 \%$, so it can be concluded that the more conducive the existing madrasa organizational climate, the higher the performance of teachers in Babakan sub-district in Purwakarta.

Furthermore, the things that are thought to also affect the performance of teachers are work motivation. Work motivation is a strong movement within a person to do superior work, best influenced by motivation, expectations, and incentives to do a job in order to achieve goals. Educators who have high work motivation will carry out their duties and responsibilities with enthusiasm in an effort to achieve more optimal educational goals. In accordance with Hasanudin's research, the coefficient value of the influence of work motivation (X2) on teacher performance $(\mathrm{Y})$ is 1.065 , meaning that when teacher work motivation is high, teacher performance will also increase. The findings support the theory of Buhler (2004: 191) and are the same as the research results of Morales, 
Reche and Torres (2008), Y. Sutomo (2006) which concludes that someone who has high work motivation has an effect on his performance in carrying out his duties.

\section{Theoretical Review :}

According to the language of performance means something that is achieved, demonstrated achievement, and work ability, and in terms of management science, the meaning of performance is almost the same. Bernardin and Russell cited by Suharsaputra, performance is "performance is defined as the record of outcomes produced on a specified job function or activity during a specific time period."

Performance is a record of the product results of a particular job function or activity over a certain period of time. So performance can be said as an achievement of performance or work performance (Performance) is defined as an expression of ability based on knowledge, attitudes, skills and motivation in producing something. So the notion of teacher performance is the re sult of work/behavior shown by an educator in his work such as; guiding, educating, instilling character values, directing students towards adulthood and the effectiveness of educators in carrying out their duties and responsibilities which can influence students to the desired goals.

Achmad S. Ruky provides an overview of the factors of individual-oriented performance appraisal, namely: 1) dedication, 2) honesty, 3) loyalty, 4) initiative, 5) willingness to work, 6) cooperation, 7) work performance, 8) development, 9) responsibility, 10) work discipline. Moeheriono defines performance indicators as: 1) Performance indicators are certain values or characteristics used to measure the output or outcome of an activity. 2) As a measuring tool used to determine the degree of success of an organization in achieving its goals.

Supervision comes from the two words "super" (above) and "vision" (see), in Webster's dictionary the term super means "higher in rankor position than, superior to (superintendent). A greater or better than others" (1991:1343) while the word vision means "the ability to perceive something not actually visible, as through mental acuteness or keen foresight" (1991:1492).

The definition of supervision put forward by John C. Daresh, namely: Supervision is a process of everseeing the ability of people to meet the goals of the organization in which they work. He stresses that supervision should be seen as a process rather than as a professional role. According to Kimball Wiles (1967), suggests that "Supervisions is assistance in the developmental of a better teaching learning situation". Supervision is an aid in the development of better learning situations. This formulation implies that the supervision service covers the entire situation in the learning process (goals, materials, technique, method, teacher, student, and environment). Supervision steps consist of three steps 1. Planning, 2. Implementation. a) Pre Observation, b) Observation and c) Post Observation) and 3. Followup.

Climate according to language is defined as "atmosphere, circumstances". Meanwhile, according to the term understanding of climate is an atmosphere or condition created by the interaction of all personnel in it. The word organization comes from the Greek word organon which means tool. There are several definitions of organization which are explained by the following experts: 1) Chester I. Barnard, defines oerganisasi is a system of cooperation between two or more people. 2) James D. Mooney, stated that the organization is any form of cooperation to achieve a common goal. 3) Sondang P. Siagian stated that organization climate organization is any form of alliance between two or more people who work together and are formally related in the context of achieving a predetermined goal, in a bond there is a person/several people called subordinates. 4) Philiph Selznic, organization is a personal arrangement to facilitate the achievement of several goals that have been set through the allocation of functions and responsibilities.

A conducive madrasa organizational climate is a prerequisite for the implementation of an effective teaching and learning process. A safe and orderly madrasa environment, optimism and high expectations from madrasa residents, madrasa health, and student-centered activities are examples of a madrasa organizational climate that fosters student learning enthusiasm.

Motif from the word movere which means "to move" or to move. So, motivation is defined as a force contained within the organism that encourages it to act or is a driving force. In the language of religion, the term motivation according to Tayar Yusuf is not much different in meaning from "intention/intention", (Innamal 'a'amalu binniat actually depends on the intention), namely the tendency of the heart that encourages someone to do something. 
Motivation comes from the word 'motive' which means encouragement/strength. When examined more deeply, the motive can be interpreted as the power contained in the individual, which causes the individual to act or act to achieve certain goals. Alice (2004) states that teacher work motivation is the factors that encourage a teacher to do his job, more enthusiastically so that he will get better performance.

\section{Research Method:-}

This type of research is associative research with quantitative descriptive methods and designs. The population of 723 teachers in 36 Madrasah Aliyah in North Lampung, the sample was taken using a cluster random sampling technique with multi stage (two stages).

$10 \%$ is as follows: The data collection tool used in this study was a questionnaire to obtain data on the four variables of Teacher Performance, Academic Supervision, Organizational Climate and Teacher Work Motivation. Data analysis is Prerequisite Test Hypothesis Testing with Path Analysis

\section{Results and Discussion:-}

The academic supervision of the Madrasah Principal has a positive and significant effect on teacher work motivation with a contribution of $42.3 \%$. Thus, teacher work motivation can be increased by making effective academic supervision of the Head of Madrasah Head of Madrasah Aliyah;

The organizational climate of Madrasah Aliyah has a positive and significant effect on teacher work motivation with a contribution of $43.2 \%$. Thus, teacher work motivation can be increased by developing and strengthening the organizational climate in Madrasah Aliyah;

The academic supervision of the Madrasah Principal and the organizational climate in Madrasah Aliyah together have been shown to have a positive and significant effect on teacher work motivation with a contribution of 37.5\%. Partially, the organizational climate is more dominant in influencing the work motivation of teachers. Thus, teacher work motivation can be increased by developing and strengthening the organizational climate of Madrasah Aliyah and streamlining the academic supervision of the Head of Madrasah Head of Madrasah Aliyah;

Academic supervision of Madrasah Principals has been proven to have a positive and significant effect on teacher performance with contributions. The amount of direct influence contribution or contribution is $35.6 \%$. The amount of contribution or contribution of indirect influence is $12.3 \%$. So that the total contribution, either directly or indirectly, is $44.9 \%$ and the remaining $55.1 \%$ is influenced by other factors that are not in this study. Thus, teacher performance can be improved by making the academic supervision of the Head of Madrasah effective directly;Organizational climate at Madrasah Aliyah has been shown to have a positive and significant effect on teacher performance with contributions. The amount of contribution or contribution of direct influence of organizational climate on teacher performance is $04.6 \%$. The contribution or contribution of indirect influence is $07.1 \%$. So that the total contribution, either directly or indirectly, is $11.7 \%$ and the remaining $88.3 \%$ is influenced by other factors that are not in this study. Thus, teacher performance can be improved by developing and strengthening the organizational climate in Madrasah Aliyah;

The academic supervision of the Madrasah Head and the organizational climate at Madrasah Aliyah have been shown to have a positive and significant effect on teacher performance. The amount of contribution or Iorganization is any form of alliance between two or more people who work together and are formally related in the context of achieving a predetermined goal, in a bond there is a person/several people called subordinates.

Academic supervision of Madrasah Principals has been proven to have a positive and significant effect on teacher performance with contributions. The amount of direct influence contribution or contribution is $35.6 \%$. The amount of contribution or contribution of indirect influence is $12.3 \%$. So that the total contribution, either directly or indirectly, is $44.9 \%$ and the remaining $55.1 \%$ is influenced by other factors that are not in this study. Thus, teacher performance can be improved by making the academic supervision of the Head of Madrasah effective directly;

Organizational climate at Madrasah Aliyah has been shown to have a positive and significant effect on teacher performance with contributions. The amount of contribution or contribution of direct influence of organizational climate on teacher performance is $04.6 \%$. The contribution or contribution of indirect influence is $07.1 \%$. So that the total contribution, either directly or indirectly, is $11.7 \%$ and the remaining $88.3 \%$ is influenced by other factors that 
are not in this study. Thus, teacher performance can be improved by developing and strengthening the organizational climate in Madrasah Aliyah;

The positive and significant influence of Madrasah Principal's academic supervision on Teacher's work motivation has the implication that the ability and quality of Madrasah Principal's academic supervision increases will be able to increase Teacher's work motivation, and vice versa if the ability and quality of Madrasah Principal's academic supervision decreases it will beable to reduce work motivation Teacher. The improvement of the dimensions of the lowest academic supervision of the Head of Madrasah is supervision, where the ability of the Head of Madrasah in planning, implementing and following up on supervision can be improved by participating in educational supervision training. In addition, improving the lowest indicator, namely the follow-up of academic supervision in analyzing the results of the follow-up of academic supervision, is still not used as a school program in improving teacher performance on an ongoing basis. When the results of the supervision of the IPKG instrument on 4 teacher competencies are not understood or most of the low scores obtained by the teacher in their pedagogical competence, namely the method used by the teacher is monotonous, then the madrasa head should provide the treatment by holding a learning methodology workshop, if not much understand and apply assessment authentic and HOTS, then the treatment of the teachers by programming assessment workshops, and so on.

The positive and significant influence of Organizational Climate on Teacher's Work Motivation has the implication that developing and strengthening the Organizational Climate in Madrasah Aliyah will be able to increase Teacher's work motivation, and vice versa if there is no effort to develop and strengthen Organizational Climate, Teacher's work motivation decreases. Improvement of the dimensions of the lowest organizational climate, namely attention to madrasas and a caring attitude towards problems can be done by paying attention to and giving teachers rights properly and applying effective assessments. In addition, improving the lowest indicator, namely a conducive working atmosphere like at Madrasah Aliyah, made me not think about changing professions and looking for other jobs by creating comfortable working conditions; The results of the study prove that madrasas have a conducive organizational climate, namely MA in Islamic boarding schools, because they are based on their teaching motivation which is sincere work, smart work, hard work and thorough work. Whereas in MAN 1 and 2North Lampung, the results of the study show that the facilities and infrastructure tend to be comfortable, complete and the situation and leadership style tend to be disciplined, so that the organizational climate is built more comfortable, disciplined and controlled. Because the head of the madrasa is professional and can control it Because there is CCTV in all rooms and school environments. This is what makes MAN more conducive. Meanwhile, those who are not in Islamic boarding schools and private schools are less conducive.

The positive and significant influence of the Headmaster's academic supervision and Organizational Climate together on the Teacher's work motivation has the implication that the quality of the Madrasah Head's academic Supervision and Organizational Climate increases it will increase the Teacher's work motivation, and vice versa if the quality of the Madrasah Principal's academic Supervision increases and Organizational Climate declines it will be able to reduce Teacher's work motivation. Organizational climate has a greater contribution than the academic supervision of the Head of Madrasah so that in priority, improvements to the organizational climate are carried out first and then the Academic Supervision of the Head of Madrasah to have a more effective impact. In accordance with the results of the study, there were three organizational climates recorded, so that each of them should be considered and improved which dimension is low. In MAN, the dimensions of the organizational climate are low The concern and participation in carrying out school activities need to be increased. For MA who are in the pesantren environment, they should improve their discipline and improve comfortable facilities and infrastructure, so that they are conducive. Likewise, the private sector and not in the pesantren, so that all dimensions of the organizational climate should be improved, because the average questionnaire results are still of insufficient and sufficient level, none of them are good or very good. When all have been given treatment according to their shortcomings, the performance of teachers will increase and education in MA will be of high quality.

The positive and significant effect of Madrasah Principal's academic supervision on Teacher Performance has the implication that an increase in the ability and quality of Madrasah Principal's academic supervision will be able to improve Teacher Performance, and vice versa if the ability and quality of Madrasah Principal's academic Supervision decreases it will be able to reduce Teacher Performance. In addition, the work motivation of teachers also contributes in helping to increase and decrease teacher performance indirectly. For this reason, steps to improve the ability of the Head of Madrasah in planning, implementing and following up on supervision can be continued together with increasing the ability of the Head of Madrasah in following up on the results of supervision 
to be used as a teacher performance improvement program in the form of workshops, IHT, class visits, etc. in accordance with the results of the supervision assessment. which will be poured in PKG in the next semester. In addition to improving the indirect effect of teacher work motivation, namely the spirit to behave and think superior in learning because it has a role in increasing and decreasing teacher performance;

The positive and significant influence of Organizational Climate on Teacher Performance has the implication that developing and strengthening the Organizational Climate in Madrasah Aliyah will be able to improve Teacher Performance, and vice versa if there is no effort to develop and strengthen the Organizational Climate, Teacher Performance will decrease. In addition, the work motivation of teachers also contributes in helping to increase and decrease teacher performance indirectly. For this reason, the steps to improve the Organizational Climate are continued with the addition of the indirect influence of teacher work motivation, namely commitment and enthusiasm to behave and think superior in learning in learning because it has a role in increasing and decreasing teacher performance;

The positive and significant influence of the Headmaster's academic supervision and Organizational Climate together on Teacher Performance has the implication that the quality of Madrasah Head's academic Supervision and Organizational Climate increases it will improve Teacher Performance, and vice versa if the quality of Madrasah Principal's Academic Supervision and Climate Organizations decline it will be able to reduce teacher performance. In addition, the work motivation of teachers also contributes in helping to increase and decrease teacher performance indirectly. For this reason, the combined steps to improve the academic supervision of the Head of Madrasah and Organizational Climate are continued with the addition of the indirect influence of the teacher's work motivation, namely caring about the level and qualification of students' graduation because it has a role in increasing and decreasing teacher performance;

The positive and significant influence of teacher work motivation on teacher performance has the implication that an increased ability of teacher work motivation will be able to improve teacher performance, and vice versa if the ability of teacher work motivation decreases it will be able to reduce teacher performance. Improvement of the dimensions of the lowest teacher work motivation, namely commitment and enthusiasm to behave and think superior in learning in learning by providing time to help students both during teaching and outside teaching time by providing decent remuneration (salary). In addition, improving the lowest indicators, namely teachers care about the level and qualifications of students' graduation, because teachers feel valued by giving teachers their rights properly;

The positive and significant influence of the Headmaster's academic supervision and Organizational Climate and Work Motivation together on Teacher Performance has the implication that the quality of Madrasah Principal's Academic Supervision and Organizational Climate and Teacher's Work Motivation together increases it will be able to improve Teacher Performance, and vice versa if the quality of the academic supervision of the head of madrasah and the organizational climate and work motivation of teachers together decrease, it will reduce teacher performance. In addition to joint steps in improving the academic supervision of the head of madrasah and organizational climate and work motivation of teachers, it is necessary to determine which priorities will be carried out. Based on the research data, the order of improvement starts from the teacher's work motivation then the organizational climate and continues with the academic supervision of the head of madrasah

\section{Conclusion:-}

Based on a series of results of research data analysis, the author can draw the conclusion that the hypothesis which reads "There is an Effect of Academic Supervision of the Head of Madrasah (X1) and Organizational Climate (X2) on Teacher Work Motivation (Z) and Its Implications on Teacher Performance (Y)" can be accepted.

\section{References:-}

1. W. Mantja, "Manajemen Pendidikan dalam Era Reformasi,".Jurnal Ilmu Pendidikan. 7,(2).Tahun 2000

2. Ahmad Maulid, Pengaruh Supervisi Kepala Madrasah dan Pengembangan Tenaga Pendidik terhadap Kinerja Guru Mas di Kabupaten Lima Puluh Kota, Jurnal Manajemen, Kepemimpinan, dan Supervisi Pendidikan Volume1, No.2, Juli-Desember 2016

3. Hasanah, Dedeh Sofia. "Pengaruh pendidikan Latihan (DIKLAT) Kepemimpinan Guru Dan Iklim Kerja terhadap Kinerja Guru Madrasah Dasarse Kecamatan Babakan Kabupaten Purwakarta."Jurnal Penelitian Pendidikan11.2(2010) 
4. Lauda, Hasanuddin,I.A. Brahmasari, and Amiartuti Kusmaningtyas."Pengaruh Transformational Leadership, Iklim Organisasi, Stres Kerja, Terhadap Kompetensi Motivasi Kerja Dan Kinerja Guru Smp Negeri Di Provinsi Sulawesi Barat."Jurnal Pendidikan Pepatudzu: Media Pendidikandan Sosial Kemasyarakatan14.2(2019)

5. Depdikbud, KamusBesar Bahasa Indonesia,(Jakarta: BalaiP ustaka, 1997), h. 503

6. Syaiful Sagala, Manajemen Strategik Dalam Peningkatan Mutu Pendidikan,(Bandung:Alfabeta,2013)

7. Barnawidan Mohammad Arifin,Kinerja Guru Profesional (Yogyakarta:Ar-Ruzz Media, 2012) Achmad S.

8. Ruky, Sistem Manajemen Kerja,(Jakarta: Gramedia Pustaka Utama, 2002),

9. Http//:pengertiansupervisi.Id/search/html/20\%.com ditulis oleh: Rina Hermawati.Diakses Pada tanggal 4 Agustus 2018

10. JohnC.Daresh, Supervision As A Proactive Process, (Newyork\&London: Longman,1990)

11. PietA. Sahertian. Konsep Dasar dan Tekhnik Supervisi Pendidikan (Dalam Rangka Pengembangan Sumber Daya Manusia) (Jakarta: Rineka Cipta2014)

12. Suharsimi Arikunto, Dasar-Dasar Supervisi,( Jakarta: Rineka Cipta,2004)

13. Dadang Suhardan, Supervisi Profesional; Layanan dalam Meningkatkan Mutu Pembelajaran di Era Otonomi Daerah, (Bandung:Alfabeta, 2010)

14. Saefullah, Manajemen Pendidikan Islam, (Bandung: Pustaka Setia, 2012) Bimo Walgito,PengantarPsikologiUmum,(Yogyakarta:Andi, 2004)

15. Tayar Yusuf dan SyaifulAnwar, Metodologi Pengajaran Agama dan Bahasa Arab, (Jakarta:Raja Grafindo Persada, 1997). 